\title{
Baroreflex Sensitivity in Children and Adolescents: Physiology, Hypertension, Obesity, Diabetes Mellitus
}

\author{
N. HONZÍKOVÁ ${ }^{1,2}$, E. ZÁVODNÁ ${ }^{1}$ \\ ${ }^{1}$ International Clinical Research Center, St. Anne's University Hospital Brno, Brno, Czech \\ Republic, ${ }^{2}$ Faculty of Health Studies, Technical University of Liberec, Liberec, Czech Republic
}

Received December 4, 2015

Accepted May 20, 2016

On-line August 19, 2016

\section{Summary}

The increased prevalence of obesity in children and its complications have led to a greater interest in studying baroreflex sensitivity (BRS) in children. This review of BRS in children and adolescents includes subtopics on: 1. Resting values of BRS and their reproducibility, 2 . Genetics of BRS, 3 . The role of a primarily low BRS and obesity in the development of hypertension, and 4. Association of diabetes mellitus, BRS, and obesity. The conclusions specific to this age follow from this review: 1 . The mean heart rate (HR) influences the measurement of BRS. Since the mean HR decreases during adolescence, HR should be taken into account. 2. A genetic dependency of BRS was found. 3. Low BRS values may precede pathological blood-pressure elevation in children with white-coat hypertension. We hypothesize that low BRS plays an active role in the emergence of hypertension in youth. A contribution of obesity to the development of hypertension was also found. We hypothesize that both factors, a primarily low BRS and obesity, are partially independent risk factors for hypertension in youths. 4. In diabetics, a low BRS compared to healthy children can be associated with insulin resistance. A reversibility of the BRS values could be possible after weight loss.

\section{Key words}

Baroreflex sensitivity • Adolescents • Hypertension • Obesity • Diabetes mellitus

\section{Corresponding author}

E. Závodná, International Clinical Research Center, St. Anne's University Hospital Brno, Pekařská 53, 65691 Brno, Czech Republic. E-mail: ezavod21@gmail.com

\section{Introduction}

The baroreflex is the most important nervous regulatory mechanism of blood-pressure homeostasis. It buffers blood-pressure variations and is also a component of long term blood-pressure regulation. The important role of baroreflex in the short-term regulation of blood pressure was proven by experiments with baroreceptors denervation; after denervation, blood pressure increased in experimental animals by over $50 \mathrm{~mm} \mathrm{Hg}$, but returned within days to its baseline value as a consequence of blood volume loss. The final result showed an increase of blood pressure variability (Cowley et al. 1973). The recent experiments with chronic electrical stimulation of the carotid sinus nerves in experiments or in therapy of hypertension resistant to antihypertensive drugs, as well as some other experiments proved the role of baroreceptors in the long term control of blood pressure (Cowley et al. 1992, Thrasher 2005, Brooks and Sved 2005, Filippone and Bisognano 2007).

Baroreflex controls the blood-pressure value through changes of the heart rate, cardiac contractility and the vascular tone, including of the capacitance vessels.

Heart-rate response to blood pressure changes is usually studied. Variations in the duration of an inter-beat interval caused by blood-pressure changes are quantified as a baroreflex sensitivity index (BRS) in $\mathrm{ms} / \mathrm{mm} \mathrm{Hg}$. Rarely, baroreflex sensitivity is quantified as a frequency response to blood pressure variations in $\mathrm{bpm} / \mathrm{mm} \mathrm{Hg}$ (Lopes et al. 2000) or as a BRSf index in $\mathrm{mHz} / \mathrm{mm} \mathrm{Hg}$ 
(Al-Kubati et al. 1997, Honzikova et al. 2006a, Nováková 2013).

BRS in adults has been studied for more than three decades. A low BRS is especially linked with cardiovascular diseases such as hypertension and myocardial infarction, or metabolic diseases such as diabetes mellitus or obesity. These diseases occur typically in adulthood and therefore it is not surprising that BRS in children is of lower interest to clinicians. Nowadays, an increased prevalence of obesity in children and its complications, as well as some other diseases with cardiovascular complications have led to a greater interest in studying BRS in children (Allen et al. 2000, Honzikova et al. 2006a, Studinger et al. 2006, McConnell et al. 2009).

This review is focused on 1) the measurement of resting values of BRS and their reproducibility in children and adolescents, 2) genetics of BRS, 3) the role of a primarily low BRS and obesity in the development of hypertension in children and adolescents, and 4) association of diabetes mellitus, BRS and obesity in children and adolescents.

\section{Resting values of baroreflex sensitivity and their reproducibility in children and adolescents}

Studies of resting BRS values in children and adolescents, and its reproducibility provided major information for its clinical application. The reported resting values of BRS in healthy children vary greatly. Quite different values of BRS were reported by Dietrich et al. (2006). They examined BRS in 1868 children between 10-13 years of age and measured values between 2.3 and $73 \mathrm{~ms} / \mathrm{mm} \mathrm{Hg}$, the median was $12.4 \mathrm{~ms} / \mathrm{mm} \mathrm{Hg}$. The highest value reported in this study seems to be abnormal. In our lab, we found smaller differences in a group of 415 subjects who were 11-20 years old (Zavodna et al. 2006), ranging between $3.9 \mathrm{~ms} / \mathrm{mm} \mathrm{Hg}$ for the 5 th percentile and $18.7 \mathrm{~ms} / \mathrm{mm} \mathrm{Hg}$ for the $95 \mathrm{th}$ percentile of measurements. This analysis was performed by using the cross-spectral method (Zavodna et al. 2006). Allen et al. (2000) measured values of BRS $19.3 \pm 9.7 \mathrm{~ms} / \mathrm{mm} \mathrm{Hg}$ by using the sequence method (this method provides generally higher values than spectral methods) in 99 children (ages 8-10) and adolescents (ages 15-17). The cross-spectral and sequence methods are explained in the mentioned studies by Zavodna et al. (2006) and by Allen et al. (2000), previously by Honzíková et al. (1992), Parati et al. (1993), and by
Persson et al. (2001).

The reproducibility of BRS in 57 children (aged 11 years) in a supine and standing position within a two week interval was evaluated by interclass correlation coefficients, standard error of measurements, coefficients of variation, limits of agreement, and Bland-Altman plots (Dietrich et al. 2010). It was found that BRS was statistically moderately reproducible while heart rate and heart rate variability were moderately-to-highly reproducible. BRS, heart rate and heart rate variability were previously shown as individually characteristic features also in adults (Honzikova et al. 1990, Jira et al. 2006, Jira et al. 2010a). Thus, all of these parameters (BRS, heart rate and heart rate variability at rest) can be applied in pediatric research despite their fluctuation over a time course (Honzikova and Zavodna 2010).

Serial analysis, allowing for early detection of a BRS decrease in individuals would be desirable for better individual risk stratification. The reliability of a BRS measurement plays a key role in the determination of mild changes of BRS at the beginning of pathological states. The spontaneous variations of BRS can influence the results of such studies as was shown in children suffering from diabetes mellitus (Svačinová et al. 2013). In this study, a continuous blood-pressure recording was taken at about one hour and BRS was determined in 14 three-minute intervals from this recording for 14 young diabetic patients and 14 age-matched control subjects. A comparison of the difference of the BRS values between the diabetic patients and the control subjects was performed for all combinations of pairs of values between diabetic patients and the control subjects. The diabetic patients had a significantly lower BRS in $26 \%$ of all combinatorial pairs. This showed that the spontaneous fluctuation of BRS was of significance for the resulting statistical evaluation of mild changes of BRS at the beginning of a disease.

The measured value of BRS is also affected by posture (Calcaterra et al. 2013), breathing rate (Honzikova et al. 1992, Frederiks et al. 2000, Calcaterra et al. 2013), and the method of measurement and calculation (Persson et al. 2001, Laude et al. 2004). However, some methodological differences are based on physiological considerations. For example, it is known that a tachycardiac response to phenylephrine is a more sensitive test for an autonomic abnormality than a bradycardiac response to a nitroglycerin administration (Lopes et al. 2000). The methodological impact on the measured value of BRS during clinical testing of BRS is 
suppressed by using the control and experimental groups which are tested under standardized conditions (for instance during the controlled breathing). The assessment of BRS is also hampered by non-baroreflex mediated heart rate variability (Frederiks et al. 1997). Using an autoregressive bivariate model, Svačinová et al. (2015) showed that the coupling between inter-beat intervals and systolic blood pressure in the feedforward mechanic direction (from inter-beat intervals to systolic blood pressure) is stronger in adolescents than that in the baroreflex direction.

Furthermore, information about the actual value of the heart rate is of importance particularly in children and adolescents, because BRS is partially dependent on a mean inter-beat interval which develops during the maturation of the autonomic control of the cardiovascular system in the period of childhood and adolescence (Závodná et al. 2006). Some other studies also examined the relationship between the heart rate and BRS in children (Allen et al. 2000). It was proposed to standardize the patients' BRS to a fixed heart rate of 60 b.p.m. by regression (Abrahamsson et al. 2003). This approach has some limitations, because the linearity between $\log$-BRS and heart rate is guaranteed only between the heart rates of 80 and 120 b.p.m. (Wesseling 2003). The BRSf index is less dependent on the inter-beat interval than the BRS index (Svačinová et al. 2013).

This observation can be explained by the way in which the variables are computed. The BRS index is derived from beat-to-beat values of inter-beat intervals (IBI); the BRSf index is derived from beat-to-beat values of the heart rate (1/IBI). An inversion proportion between IBI and 1/IBI is non-linear. Thus, in two subjects with a different mean IBI, the same value of BRS and a different value of BRSf can be calculated. Under some circumstances, the shortening of the mean IBI and a small decrease of BRS results in an increase of BRSf; when the mean IBI prolongs and BRS does not change, BRSf decreases. This effect can be mathematically explained. It explains different results in the evaluation of the development of baroreflex sensitivity during preadolescence and adolescence using BRS and BRSf indices (Závodná et al. 2006). It was shown in this study that the BRS index did not reveal any development in the ages between 11 and 15 years, while the BRSf index decreased.

The impact of the mean heart rate in the evaluation of baroreflex sensitivity can be documented also in other clinical applications. For example, it is generally accepted that a high BRS plays an important role in the prevention of sudden cardiac death in adults by buffering blood pressure variability. The efficacy of baroreflex sensitivity to suppress the systolic bloodpressure variability using BRS and BRSf indices was tested; the BRSf index in $\mathrm{mHz} / \mathrm{mm} \mathrm{Hg}$ seemed to be a better indicator of the suppression of the systolic bloodpressure variability than the BRS index in $\mathrm{ms} / \mathrm{mm} \mathrm{Hg}$ (Honzikova and Zavodna 2010).

There are only a few studies using beat-to-beat values of the heart rate in the evaluation of baroreflex sensitivity and therefore, the majority of the subsequent studies are based on the BRS index in $\mathrm{ms} / \mathrm{mm} \mathrm{Hg}$.

\section{Genetics of BRS}

The investigation of the genetic dependency of baroreflex sensitivity is not simple, because blood pressure control by baroreflex is dependent on the sensation of arterial stretch in baroreceptors in the carotid arteries and aortic walls, on afferent signals brought by glossopharyngeal and vagal nerves to the brainstem, on the integration of those signals with cortical input and other autonomic reflexes, and finally on efferent signaling by sympathetic and parasympathetic pathways. On the other hand, even modest changes of baroreflex function through genetic mechanisms could influence the blood-pressure and heart-rate regulation.

Previous studies have estimated the heritability of baroreflex sensitivity in twins (Tank et al. 2001a).

Some studies have shown that baroreflex sensitivity is diminished in young normotensive subjects who have hypertensive parents in comparison with those without a family history of hypertension (Palmer et al. 1992, Lopes et al. 2000). This implies that decreased BRS is a potential cause of hypertension and therefore genetic studies are of importance.

Nowadays, some studies have described associations between several gene polymorphisms and baroreflex heart-rate regulation, but it is necessary to stress that these are only first attempts in genetic baroreflex studies. The results are sometimes inconsistent. The cause could be in a complicated control loop involved in baroreflex heart-rate regulation. Polymorphisms in genes reported as those associated with BRS value, mainly its decrease, are genes for the endotelin-A receptor (Ormezzano et al. 2005), for the bradykinin B2 receptor (Yang et al. 2010), for the BK channel beta 1 subunit (Gollasch et al. 2002), for the 
aldosteron synthase (Ylitalo et al. 2000), and for the AT1 receptor gene (Jira et al. 2010b).

A special group of studies are those of rare genetic disorders (Williams's syndrome, brachydactyly) which include baroreflex blood-pressure buffering impairment (Girard et al. 2002, Tank et al. 2001b).

\section{The role of a primarily low BRS and obesity in the development of hypertension in children and adolescents}

In obese subjects, more mechanisms leading to blood-pressure elevation have been identified. It was especially shown that obesity leads to an increased sympathetic activity via the leptin (Rahmouni et al. 2005), hormone secreted by adipocytes proportionally to the fat mass content. It acts in hypothalamus and, besides a suppression of food intake, it also increases sympathetic activity. Hypertension in obesity is explained by a leptin resistance to the appetite reducing activity together with preservation of the sympathetic activation. Leptin also acts within the solitary tract nucleus relating to baroreflex modulation. This was documented in experiments performed on rats by leptin microinjection in this region. Leptin impaired baroreflex sensitivity for bradycardia induced by increases in arterial blood pressure (Arnold et al. 2009).

The prevalence of obesity increases not only in adults, but also in adolescents. It is hypothesized that it could be linked with an increased prevalence of hypertension in adolescents and young adults. The data on the epidemics of obesity are alarming. Therefore the linkage between obesity and pathologic blood pressure elevation in adolescents is now studied.

In hypertensive adult patients low BRS is present, usually under $5 \mathrm{~ms} / \mathrm{mm} \mathrm{Hg}$ (Honzíková et al. 2006 b). It was proven that low BRS in adult patients with essential hypertension was associated with increased thickness and stiffness of the carotid arteries (Gianaros et al. 20002, Labrova et al. 2005, Honzikova et al. 2006b). Thus, structural changes of the carotid wall linked to hypertension and increased stiffness of the carotid arteries lead to a lower carotid distensibility and lower baroreceptors' stimulation. This means BRS decreases in hypertonic patients as a consequence of this disease.

On the basis of our studies we hypothesize that low BRS plays an active role in the emergence of hypertension in children and adolescents. Low BRS was repeatedly described in children and adolescents with a pathologic elevation of blood pressure and obesity (Honzíková et al. 2006a, Krontorádová et al. 2008, Lazarová et al. 2009). A possible explanation is that leptin was acting within the solitary tract nucleus relating to baroreflex modulation, as explained by Arnold et al. (2009).

Decreased baroreflex gain as a predictive factor for the subsequent development of arterial hypertension was identified during a five-year follow-up study (Ducher et al. 2006). On the other hand, it was found that the value of BRS was lower than $3.5 \mathrm{~ms} / \mathrm{mm} \mathrm{Hg}$ in $5 \%$ of 415 healthy subjects aged between 11 and 19 years (Závodná et al. 2006). Such low BRS approximated the critical value of BRS for sudden cardiac death in patients after myocardial infarction (Honzíková et al. 2000). This corresponded to the value that we found in the adult hypertonic patients (Honzíková et al. 2006b) who were examined in our laboratory by the identical BRS-measurement as were the children. This indicated that the later development of hypertension could be to some extent predetermined by low BRS in childhood; maybe an inborn low BRS could be one of the risk factors for essential hypertension in adults. The study in children and adolescents with white-coat hypertension supported this hypothesis. These children had lower BRS than healthy control subjects (Honzíková et al. 2006a). The situation in children or adolescents with white-coat hypertension is different from adult hypertonic patients with increased carotid stiffness. These children have physiological blood pressure over $24 \mathrm{~h}$. Hence, it is unlikely that blood pressure caused vascular wall remodeling. This finding might suppose the interpretation that low BRS precedes blood pressure elevation in these children.

From previous information on low BRS and obesity in hypertensive children and adolescents the question arises, as to how firmly both factors are interrelated in the process of blood-pressure elevation. Direct evidence that both obesity and low baroreflex sensitivity are partially independent risk factors in the development of essential hypertension was provided by Krontoradova et al. (2008). In this study hypertonic children had significantly lower BRS and significantly higher BMI in comparison with healthy subjects. On the other hand, no correlation was found between BMI and BRS either in hypertonic or in control subjects. The predicting power of BMI, BRS, and a combination of both factors determined by logistic regression analysis for hypertension was evaluated in terms of sensitivity and 
specificity. This method for the evaluation of more fuzzyfied-weighted-summed risk factors was explained by Honzik et al. (2003, 2010). The optimal threshold was determined by receiver operating curves (ROCs). Also, the area under the ROC curve was calculated. The sensitivity, specificity, and area under the ROC were increased for a summed risk factor (for BRS and BMI) in comparison with separate factors in predicting hypertension. All of the above explained facts documented that obesity and primarily low BRS additively cause pathologic blood-pressure elevation in children and adolescents.

Changes in sympathetic activity and baroreflex sensitivity influence not only the mean blood pressure and heart rate, but also blood-pressure and heart-rate variability. It is necessary to stress that a direct, positive relationship has been established between 24-h blood pressure variability and the severity and rate of progression of end-organ damage (Mancia and Parati 2003).

Therefore it is important to investigate what is the relationship between the short term systolic-bloodpressure (SBP) and/or inter-beat interval (IBI) variability on one hand, and the sympathetic activation or hypertension on the other hand. Relationships between BRS, SBP and IBI variability at a frequency of $0.1 \mathrm{~Hz}$ were studied in healthy adults during exercise (Honzikova et al. 2003). Causal interrelationships between variables at $0.1 \mathrm{~Hz}$ frequency were shown: 1) a higher BRS was linked with a higher variability of inter-beat intervals and a better suppression effect on blood-pressure variability; 2) variabilities in inter-beat intervals and blood pressure were nearly linearly related at a given BRS value; 3) primary variability in SBP was different in different subjects, and furthermore, it increased due to a sympathetic activation during exercise. This third finding is very important with respect to similar studies in hypertensive children.

After proving primarily increased SBP variability during sympathetic activation in exercise, we decided to evaluate short term SBP and IBI variability in children, adolescents and young adults with essential and white-coat hypertension (Honzikova et al. 2006a). In this study the $0.1 \mathrm{~Hz}$ variability in SBP and IBI, together with the body mass index, BRS and BRSf, and mean IBI from 5 min of recording were evaluated. In addition to a step by step increase of the body mass index from control subjects with white-coat hypertension and hypertensives, a step by step decrease of BRS and BRSf was present.
Surprisingly, an increase of SBP variability was not linked with a significant change of IBI or IBI variability. This could be explained by lower BRS.

Interrelationships between $0.1 \mathrm{~Hz}$ variability of SBP and IBI, and BRS were further studied in hypertensive adolescents. Patients were divided into 9 subgroups with respect to their value of $0.1 \mathrm{~Hz}$ variability of SBP and IBI (high, middle, low). Hypertensive adolescents were found in subgroups with the highest SBP variability in comparison to control subjects. This finding suggests the increased sympathetic activation leading to high blood pressure variability, which was insufficiently suppressed despite high heartrate variability. On the other hand, the IBI variability in some hypertensive subjects was middle or low (Zavodna et al. 2014). The explanation for a combination of high variability in SBP and low variability in IBI could actually lie in the low value of BRS. In conclusion, the mechanisms of autonomic control of the circulation, an increased sympathetic activation and low baroreflex sensitivity, are all linked with the elevation of blood pressure in adolescents.

\section{Association of diabetes mellitus, BRS and obesity in children and adolescents}

Diabetic neuropathy is one of the serious complications of diabetes mellitus in adults, which has a negative impact on quality of life and the survival of such patients as already discovered 40 years ago (Ewing and Clarke 1982). Cardiovascular neuropathy is the clinically most important form of diabetic autonomic neuropathy (Vinik et al. 2003). Early detection of subclinical autonomic dysfunction in diabetic patients is of vital importance for these patients (Schroeder et al. 2005). Therefore, the attention of studies of cardiovascular autonomic dysfunction has also turned to children and adolescents.

Studies of heart rate and blood pressure variability provided evidence for an early increase of power of the low-frequency component in the blood pressure spectra (Lucini et al. 2009) and a decrease of the high-frequency component in the spectra of RR intervals (Laederach-Hofman et al. 1999, Javorka et al. 2005, Krause et al. 2009). These changes were signs of increased sympathetic and decreased parasympathetic activity. Previously, autonomic dysfunction in patients suffering from diabetes mellitus with respect to diminished BRS was studied mostly in adults. 
Nevertheless, BRS was also studied in diabetic children and adolescents and the results were very similar baroreflex sensitivity was suppressed (Boysen et al. 2007, Dalla Pozza et al. 2007, Krause et al. 2009, Lucini et al. 2009, Javorka et al. 2011) in diabetic patients. The degree of BRS decrease was related to the duration of the disease (Dalla Pozza et al. 2007) and to the quality of the control of glycemia examined as HbAlc (Krause et al. 2009).

Moreover, sympathetic overactivity, caused by an increase of the plasma level of insulin, leptin, or angiotensin II was involved in the reduction of BRS (Straznicky et al. 2008).

It was reported in the previous part of this article that obesity can lead to a reduction in spontaneous BRS not only in adults, but also in children (Lazarova et al. 2009, Dangardt et al. 2011). Therefore the information regarding whether the autonomic abnormalities in obese children with insulin resistance result from a structural or still only functional impairment is of clinical importance. The reactivity of BRS in obese children and adolescents with insulin resistance was tested by Calcaterra et al. (2013). Obese participants were able to increase BRS in response to slow deep breathing and to decrease BRS during active standing in a similar way as healthy normalweight children. They showed that despite low resting BRS values, when stimulated, it appeared that cardiovascular regulation was still operative.

It can be supposed that the starting autonomic dysfunction in these children is functional and its reversibility could be possible after weight loss. The same effect of slow deep breathing was described in young diabetics between 18 and 35 years of age with the duration of diabetes of 6 to 12 years (Rosengard-Barlund et al. 2009). On the other hand, thickening and stiffening of the arterial wall was detected in children and adolescents with diabetes mellitus type I (Atabek et al. 2006). The longitudinal carotid intima-media thickness measurements revealed a progression in subclinical atherosclerosis over a four year period in diabetic children and adolescents. It increased with BMI, blood pressure, HbAlc, and duration of the diabetes (Dalla Pozza et al. 2011). Thickening and stiffening of the arterial wall leads to the suppression of BRS, it develops with a longer duration of a metabolic disease.

Several studies concentrated on patients with diabetes mellitus type I who were usually slim but still exhibited the signs of autonomic dysfunction in the early stage of the disease. Decreased BRS which was not linked to obesity was described in these patients (Boysen et al. 2007). Some authors published divergent results. Scaramuzza et al. (1998) did not find any significant difference in BRS between diabetic patients and control subjects.

It is necessary to mention a specific problem in BRS determination in children and adolescents. Besides the spontaneous variations of BRS, it is the development of the mean heart rate as Svačinová et al. (2013) has shown and as was explained in the physiologic part of this review. Because BRS in childhood is partially dependent on the mean inter-beat interval which develops during maturation of the autonomic control of the cardiovascular system in the age, BRS reflects not only an impairment of the quick baroreflex responses of interbeat intervals to blood pressure changes in young diabetic patients, but also a change of the tonic sympathetic and parasympathetic heart rate control. This fact complicates the interpretation of some studies.

A disturbance of the baroreflex loop in diabetic neuropathy can be characterized not only by its gain, e.g. BRS, but also by a prolongation of the baroreflexloop time delay between oscillations in blood pressure and inter-beat intervals assessed by a time-domain crosscorrelation method (Javorka et al. 2011). This means, the frequency at which baroreflex control of blood pressure operates can be supposed to be the next characteristic of this system, being possibly dependent on baroreflex control of peripheral resistance. This branch of baroreflex operates at a frequency of about $0.1 \mathrm{~Hz}$ (Sayers 1973) and therefore it is used for the determination of BRS. The frequency of the maximum spectral peak in the cross-spectra of systolic blood pressure and IBI fluctuations in the low frequency range was decreased in diabetics (Honzíková et al. 2012). It was examined in a small group of young patients with diabetes mellitus type I (14 patients, 20-24 years of age, DM duration 10-14 years). The frequency peak (f) of maximal power in the cross-spectra between the variability in blood pressure and IBI was determined in a frequency range of 0.06-0.12 Hz. Risk stratification using BRS, (f) and a combinatory index of both factors showed that a shift of (f) to lower frequencies could provide a new diagnostic tool for the detection of autonomic nervous system impairment in diabetic patients. On the other hand, a major shortcoming of this study was the small size of the tested group. 


\section{Conclusions}

Several characteristics of baroreflex sensitivity (BRS; in $\mathrm{ms} / \mathrm{mm} \mathrm{Hg}$ ) which are specific to children and adolescents are summarized in this review. The mean heart rate influences the measurement of BRS. Since the mean heart rate decreases during the maturation of the autonomic nervous system, heart rate should be taken into account for baroreflex sensitivity calculation in children and adolescents. One of the possibilities is calculation of an index BRSf in $\mathrm{mHz} / \mathrm{mm} \mathrm{Hg}$, which is determined by using instantaneous values of heart rate instead of interbeat intervals. This approach is not used frequently. It was shown that the index BRS is unchanged whereas the index BRSf decreases in the age between 10 and 20 years.

A genetic dependency of BRS was found. This is in accordance with the information that BRS lower than $4 \mathrm{~ms} / \mathrm{mm} \mathrm{Hg}$ (the value typical of adult hypertensive patients) is found in about $5 \%$ of a healthy young population. The finding of pathologically low BRS precedes a pathological blood-pressure elevation in children with white-coat hypertension. We formulated the hypothesis that low BRS plays an active role in the emergence of hypertension in children and adolescents.
A contribution of obesity to the development of hypertension was also found. We have proved that both factors, a primarily low BRS and obesity, are partially independent risk factors for hypertension in youths.

In diabetics, a low BRS compared to healthy children can be associated with insulin resistance. A reversibility of the BRS values could be possible after weight loss.

In conclusion, low baroreflex sensitivity provides information on cardiovascular dysregulation in the young normotensive obese population, and patients with hypertension or diabetes mellitus type I and II. Low BRS can be inborn and may play an active role in pathological blood-pressure elevation in children and adolescents.

\section{Conflict of Interest}

There is no conflict of interest.

\section{Acknowledgement}

This study was supported by the European Regional Development Fund - Project FNUSA-ICRC (no. CZ.1.05/1.1.00/02.0123) and by the project no. LQ1605 (MEYS CR, NPU II).

\section{References}

ABRAHAMSON C, AHLUND C, NORDLANDER M, LIND L: A method for heart-rate corrected estimation of baroreflex sensitivity. J Hypertens 21: 2133-2140, 2003.

AL-KUBATI MAA, FISER B, SIEGELOVA J: Baroreflex sensitivity during psychological stress. Physiol Res 46: 27-33, 1997.

ALLEN MT, MATTHEWS KA, KENYON KL: The relationships of resting baroreflex sensitivity, heart rate variability and measures of impulse control in children and adolescents. Int J Psychophysiol 37: 185-194, 2000.

ARNOLD AC, SHALTOUT HA, GALLAGHER PE, DIZ DI: Leptin impairs cardiovagal baroreflex function at the level of the solitary tract nucleus. Hypertension 54: 1001-1008, 2009.

ATABEK ME, KURTOGLU S, PIRGON O, BAYKARA M: Arterial wall thickening and stiffening in children and adolescents with type 1 diabetes. Diabetes Res Clin Pract 74: 33-40, 2006.

BOYSEN A, LEWIN MAG, HECKER W, LEICHTER HE, UHLEMANN F: Autonomic function testing in children and adolescents with diabetes mellitus. Pediatr Diabetes 8: 261-264, 2007.

BROOKS VL, SVED AF: Pressure to change? Re-evaluating the role of baroreceptors in the long-term control of arterial pressure. Am J Physiol Regul Integr Comp Physiol 288: R815-R818, 2005.

CALCATERRA V, VANDONI M, DEBARBIERI G, LARIZZA D, ALBERTINI R, ARPESELLA M, BERNARDI L: Deep breathing improves blunted baroreflex sensitivity in obese children and adolescents with insulin resistance. Int J Cardiol 168: 1614-1615, 2013.

COWLEY AW JR: Long-term control of arterial blood pressure. Physiol Rev 72: 231-280, 1992.

COWLEY AW JR, LIARD JF, GUYTON AC: Role of baroreceptor reflex in daily control of arterial blood pressure and other variables in dogs. Circ Res 32: 564-576, 1973. 
DANGARDT F, VOLKMANN R, CHEN Y, OSIKA W, MARILD S, FRIBERG P: Reduced vagal activity in obese children and adolescents. Clin Physiol Funct Imaging 31: 108-113, 2011.

DALLA POZZA R, BECHTOLD S, BONFIG W, PUTZKER S, KOZLIK-FELDMANN R, SCHWARZ HP, NETZ H: Impaired short-term blood pressure regulation and autonomic dysbalance in children with type 1 diabetes mellitus. Diabetologia 50: 2417-2423, 2007.

DALLA POZZA R, BEYERLEIN A, THILMANY C, WEISSENBACHER C, NETZ H, SCHMIDT H, BECHTOLD $\mathrm{S}$ : The effect of cardiovascular risk factors on the longitudinal evolution of the carotid intima medial thickness in children with type 1 diabetes mellitus. Cardiovasc Diabetol 10: 53-61, 2011.

DIETRICH A, RIESE H, VAN ROON AM, VAN ENGELEN K, ORMEL J, NEELEMAN J, ROSMALEN JG: Spontaneous baroreflex sensitivity in (pre)adolescents. J Hypertens 24: 345-352, 2006.

DIETRICH A, ROSMALEN JGM, ALTHAUS M, VAN ROON AM, MULDER LJM, MINDERAA RB, OLDEHINKEL AJ, RIESE H: Reproducibility of heart rate variability and baroreflex sensitivity measurements in children. Biol Psychol 85: 71-78, 2010.

DUCHER M, FAUVEL JP, CERUTTI C: Risk profile in hypertension genesis: a five-year follow-up study. $A m \mathrm{~J}$ Hypertens 19: 775-780, 2006.

EWING DJ, CLARKE BF: Diagnosis and management of diabetic autonomic neuropathy. Br Med J (Clin Res Ed) 285 : 916-918, 1982.

FILIPPONE JD, BISOGNANO JD: Baroreflex stimulation in the treatment of hypertension. Curr Opin Nephrol Hypertens 16: 403-408, 2007.

FREDERIKS J, SWENNE CA, TENVOORDE BJ, HONZIKOVA N, LEVERT JV, MAAN AC, SCHALIJ MJ, BRUSCHKE AVG: Non-baroreflex mediated heart rate variability causes overestimation of baroreflex sensitivity. Comput Cardiol 24: 199-202, 1997.

FREDERIKS J, SWENNE CA, TENVOORDE BJ, HONZIKOVA N, LEVERT JV, MAAN AC, SCHALIJ MJ, BRUSCHKE AVG: The importance of high-frequency paced breathing in spectral baroreflex sensitivity assessment. J Hypertens 18: 1635-1644, 2000.

GIANAROS PJ, JENNINGS JR, OLAFSSON GB, STEPTOE A, SUTTON-TYRRELL K, MULDOON MF, MANUCK SB: Greater intima-media thickness in the carotid bulb is associated with reduced baroreflex sensitivity. Am J Hypertens 15: 486-491, 2002.

GIRARD A, SIDI D, AGGOUN Y, LAUDE D, BONNET D, ELGHOZI JL: Elastin mutation is associated with a reduced gain of the baroreceptor-heart rate reflex in patients with Williams syndrome. Clin Auton Res 12: 72-77, 2002.

GOLLASCH M, TANK J, LUFT F, JORDAN J, MAASS P, KRASKO C, SHARMA AM, BUSJAHN A, BAHRING $\mathrm{S}$ : The BK channel $\beta 1$ subunit gene is associated with human baroreflex and blood pressure regulation. J Hypertens 20: 927-933, 2002.

HONZIK P, HRABEC J, LABROVA R, SEMRAD B, HONZIKOVA N: Fuzzification, weight and summation of risk factors in a patient improves the prediction of risk for cardiac death. Scr Med 76: 141-148, 2003.

HONZÍK P, KŘIVAN L, LOKAJ P, LÁBROVÁ R, NOVÁKOVÁ Z, FIŠER B, HONZÍKOVÁ N: Logit and fuzzy models in data analysis: estimation of risk in cardiac patients. Physiol Res 59 (Suppl 1): S89-S96, 2010.

HONZIKOVA N, ZAVODNA E: Is low baroreflex sensitivity only a consequence of essential hypertension or also a factor conditioning its development? In: Genetics and Pathophysiology of Essential Hypertension. KHULLAR M (ed.), InTech, 2010, pp 67-88.

HONZIKOVA N, FISER B, HONZIK J: Noninvasive determination of baroreflex sensitivity in man by means of spectral analysis. Physiol Res 41: 31-37, 1992.

HONZÍKOVÁ N, SEMRÁD B, FIŠER B, LÁBROVÁ R: Baroreflex sensitivity determined by spectral method and heart rate variability, and two-years mortality in patients after myocardial infarction. Physiol Res 49: 643-650, 2000.

HONZÍKOVÁ N, KRTIČKA A, NOVÁKOVÁ Z, ZÁVODNÁ E: A dampening effect of pulse interval variability on blood pressure variations with respect to primary variability in blood pressure during exercise. Physiol Res 52: 299-309, 2003. 
HONZÍKOVÁ N, NOVÁKOVÁ Z, ZÁVODNÁ E, PADĚROVÁ J, LOKAJ P, FIŠER B, BALCÁRKOVÁ P, HRSTKOVÁ H: Baroreflex sensitivity in children, adolescents, and young adults with essential and white-coat hypertension. Klin Paed 218: 237-242, 2006a.

HONZÍKOVÁ N, LÁBROVÁ R, FIŠER B, MADĚROVÁ E, NOVÁKOVÁ Z, ZÁVODNÁ E, SEMRÁD B: Influence of age, body mass index, and blood pressure on the carotid intima-media thickness in normotensive and hypertensive patients. Biomed Tech 51: 159-162, $2006 \mathrm{~b}$.

HONZÍKOVÁ N, KRTIČKA A, ZÁVODNÁ E, JAVORKA M, TONHAJZEROVÁ I, JAVORKA K: Spectral peak frequency in low-frequency band in cross spectra of blood pressure and heart rate fluctuations in young type I diabetic patients. Physiol Res 61: 347-354, 2012.

JAVORKA M, JAVORKOVA J, TONHAJZEROVA I, JAVORKA K: Parasympathetic versus sympathetic control of the cardiovascular system in young patients with type 1 diabetes mellitus. Clin Physiol Funct Imaging 25: 270-274, 2005.

JAVORKA M, LAZAROVA Z, TONHAJZEROVA I, TURIANIKOVA Z, HONZIKOVA N, FISER B, JAVORKA K, BAUMERT M: Baroreflex analysis in diabetes mellitus: linear and nonlinear approaches. Med Biol Eng Comput 49: 279-288, 2011.

JÍRA M, ZÁVODNÁ E, HONZÍKOVÁ N, NOVÁKOVÁ Z, FIŠER B: Baroreflex sensitivity as an individual characteristic feature. Physiol Res 55: 349-351, 2006.

JÍRA M, ZÁVODNÁ E, NOVÁKOVÁ Z, FIŠER B, HONZÍKOVÁ N: Reproducibility of blood pressure and inter-beat interval variability in man. Physiol Res 59 (Suppl 1): S113-S121, 2010a.

JÍRA M, ZÁVODNÁ E, HONZÍKOVÁ N, NOVÁKOVÁ Z, VAŠKU゚ A, IZAKOVIČOVÁ HOLLÁ L, FIŠER B: Association of A1166C polymorphism in AT1 receptor gene with baroreflex sensitivity. Physiol Res 59: $517-528,2010 \mathrm{~b}$.

KRAUSE M, RÜDIGER H, BALD M, NÄKE A, PADITZ E: Autonomic blood pressure control in children and adolescents with type 1 diabetes mellitus. Pediatr Diabetes 10: 255-263, 2009.

KRONTORÁDOVÁ K, HONZÍKOVÁ N, FIŠER B, NOVÁKOVÁ Z, ZÁVODNÁ E, HRSTKOVÁ H, HONZÍK P: Overweight and decreased baroreflex sensitivity as independent risk factors for hypertension in children, adolescents, and young adults. Physiol Res 57: 385-391, 2008.

LÁBROVÁ R, HONZÍKOVÁ N, MADĚROVÁ E, VYSOČANOVÁ P, NOVÁKOVÁ Z, ZÁVODNÁ E, FIŠER B, SEMRÁD B: Age-dependent relationship between the carotid intima-media thickness, baroreflex sensitivity, and the inter-beat interval in normotensive and hypertensive subjects. Physiol Res 54: 593-600, 2005.

LAEDERACH-HOFMANN K, MUSSGAY L, WINTER A, KLINKENBERG N, RÜDDEL H: Early autonomic dysfunction in patients with diabetes mellitus assessed by spectral analysis of heart rate and blood pressure variability. Clin Physiol 19: 97-106, 1999.

LAUDE D, ELGHOZI J-L, GIRARD A, BELLARD E, BOUHADDI M, CASTIGLIONI P, CERUTTI C, CIVIDJIAN A, Di RIENZO M, FORTRAT JO, JANSSEN B, KAREMAKER JM, LEFTHÉRIOTIS G, PARATI G, PERSSON PB, PORTA A, QUINTIN L, REGNARD J, RÜDIGER H, STAUSS HM: Comparison of various techniques used to estimate spontaneous baroreflex sensitivity (the EuroBaVar study). Am J Physiol Regul Integr Comp Physiol 286: R226-R231, 2004.

LAZAROVÁ Z, TONHAJZEROVÁ I, TRUNKVALTEROVÁ Z, BROZMANOVÁ A, HONZÍKOVÁ N, JAVORKA $\mathrm{K}$, BAUMERT M, JAVORKA M: Baroreflex sensitivity is reduced in obese normotensive children and adolescents. Can J Physiol Pharmacol 87: 565-571, 2009.

LOPES HF, SILVA HB, CONSOLIM-COLOMBO FM, BARRETO FILHO JAS, RICCIO GMG, GIORGI DMA, KRIEGER EM: Automatic abnormalities demonstrable in young normotensive subjects who are children of hypertensive parents. Brazilian J Med Biol Res 33: 51-54, 2000.

LUCINI D, ZUCCOTTI G, MALACARNE M, SCARAMUZZA A, RIBONI S, PALOMBO C, PAGANI M: Early progression of the autonomic dysfunction observed in pediatric type 1 diabetes mellitus. Hypertension 54: 987-994, 2009.

MANCIA G, PARATI G: The role of blood pressure variability in end-organ damage. J Hypertens 21: S17-S23, 2003. 
MC CONNELL K, SOMERS VK, KIMBALL T, DANIELS S, VAN DYKE R, FENCHEL M, COHEN A, WILLGING P, SHAMSUZZAMAN A, AMIN R: Baroreflex gain in children with obstructive sleep apnea. Am J Respir Crit Care Med 180: 42-48, 2009.

NOVÁKOVÁ Z: From the first spectral analysis of blood pressure variability in the world to the present time: contribution of the Department of Physiology of the Faculty of Medicine, Masaryk University, Brno. Physiol Res 62: 341-350, 2013.

ORMEZZANO O, POIRIER O, MALLION J, NICAUD V, AMAR J, CHAMONTIN B, MOUNIER-VEHIER C, FRANÇOIS P, CAMBIEN F, BAGUET JP: A polymorphism in the endothelin-A receptor gene is linked to baroreflex sensitivity. J Hypertens 23: 2019-2026, 2005.

PARATI G, OMBONI S, FRATTOLA SA, DI RIENZO M, ZANCHETTI A, MANCIA G: Dynamic evaluation of the baroreflex in ambulant subjects. In: Blood Pressure and Heart Rate Variability. DI RIENZO M, MANCIA G, PEDOTTI A, ZANCHETTI A (eds), IOS Press, Amsterdam, 1993, pp 123-137.

PARMER RJ, CERVENKA JH, STONE RA: Baroreflex sensitivity and heredity in essential hypertension. Circulation 85: 497-503, 1992.

PERSSON PB, DIRIENZO M, CASTIGLIONI P, CERUTTI C, PAGANI M, HONZIKOVA N, AKSELROD S, PARATI G: Time versus frequency domain techniques for assessing baroreflex sensitivity. $J$ Hypertens 19: 1699-1705, 2001.

RAHMOUNI K, CORRELA MLG, HAYNES WG, MARK AL: Obesity-associated hypertension: new insights into mechanisms. Hypertension 45: 9-14, 2005.

ROSENGARD-BARLUND M, BERNARDI L, FAGERUDD J, MANTYSAARI M, AF BJORKESTEN CG, LINDHOLM H, FORSBLOM C, WADEN J, GROOP PH; FINNDIANE STUDY GROUP: Early autonomic dysfunction in type 1 diabetes: a reversible disorder? Diabetologia 52: 1164-1172, 2009.

SAYERS BM: Analysis of heart rate variability. Ergonomics 16: 17-32, 1973.

SCARAMUZZA A, SALVUCCI F, LEUZZI S, RADAELLI A, D'ANNUNZIO G, FRATINO P, LORINI R, BERNARDI L: Cardiovascular autonomic testing in adolescents with type I (insulin-dependent) diabetes mellitus: an 18-month follow-up study. Clin Sci (Lond) 94: 615-621, 1998.

SCHROEDER EB, CHAMBLESS LE, LIAO D, PRINEAS RJ, EVANS GV, ROSAMOND WD, HEISS G: Diabetes, glucose, insulin, and heart rate variability. Diabetes Care 28: 668-674, 2005.

STRAZNICKY NE, EIKELIS N, LAMBERT EA, ESLER MD: Mediators of sympathetic activation in metabolic syndrome obesity. Curr Hypertens 10: 440-447, 2008.

STUDINGER P, LÉNÁRD Z, MERSICH B, REUSZ GS, KOLLAI M: Determinants of baroreflex function in juvenile end-stage renal disease. Kidney Int 69: 2236-2242, 2006.

SVAČINOVÁ J, HONZÍKOVÁ N, KRTIČKA A, TONHAJZEROVÁ I, JAVORKA K, JAVORKA M: Significance of mild decrease of baroreflex sensitivity with respect to heart rate in type 1 diabetes mellitus. Physiol Res 62 : 605-613, 2013.

SVAČINOVÁ J, JAVORKA M, NOVÁKOVÁ Z, ZÁVODNÁ E, CZIPPELOVÁ B, HONZÍKOVÁ N: Development of causal interactions between systolic blood pressure and inter-beat intervals in adolescents. Physiol Res 64: $821-829,2015$.

TANK J, JORDAN J, DIETRICH A, STOFFELS M, FRANKE G, FAULHABER HD, LUFT FC, BUSJAHN A: Genetic influences on baroreflex function in normal twins. Hypertension 37: 907-910, $2001 \mathrm{a}$.

TANK J, TOKA O, TOKA HR, JORDAN J, DIETRICH A, BUSJAHN A, LUFT FC: Autonomic nervous system function in patients with monogenic hypertension and brachydactyly: a field study in north-eastern Turkey. J Hum Hypertens 15: 787-792, 2001 b.

THRASHER TN: Effects of chronic baroreceptor unloading on blood pressure in the dog. Am J Physiol Regul Integr Comp Physiol 288: R863-R871, 2005.

VINIK AI, MASER RE, MITCHELL BD, FREEMAN R: Diabetic autonomic neuropathy. Diabetes Care 26: 1553-1579, 2003.

WESSELING KH: Should baroreflex sensitivity be corrected for heart rate? J Hypertens 21: 2015-2018, 2003.

YANG X-S, LI Y-Z, LIU J-X, GAI Y-Q, CHEN Z-H, ZHONG C-F, TANG Z-Z, LV S-Z: Genetic influence on baroreflex sensitivity in normotensive young men. Am J Hypertens 23: 655-659, 2010. 
YLITALO A, AIRAKSINEN KE, HAUTANEN A, KUPARI M, CARSON M, VIROLAINEN J, SAVOLAINEN M, KAUMA H, KESANIEMI YA, WHITE PC, HUIKURI HV: Baroreflex sensitivity and variants of the renin angiotensin system genes. $J$ Am Coll Cardiol 35: 194-200, 2000.

ZAVODNA E, HONZIKOVA N, HRSTKOVA H, NOVAKOVA Z, MOUDR J, JIRA M, FISER B: Can we detect the development of baroreflex sensitivity in humans between 11 and 20 years of age? Can J Physiol Pharmacol 84: 1275-1283, 2006.

ZAVODNA E, NOVAKOVA Z, ROHANOVA M, STASTNA J, HONZIKOVA N, HRSTKOVA H: Changes in shortterm blood pressure regulation in adolescents with type-I diabetes mellitus and essential hypertension. Comput Cardiol 41: 301-304, 2014. 